\title{
DINÂMICA DA PRECIPITAÇÃO PLUVIOMETRICA NA CIDADE DE GUARAPUAVA, PR: CONDICIONANTES LOCAIS E REGIONAIS ${ }^{1}$
}

\author{
COSTA, Claudiane da - clau_dianecosta@hotmail.com \\ Universidade Estadual do Centro-Oeste/UNICENTRO-Guarapuava/PR \\ ANDRADE, Aparecido Ribeiro - apaandrade@gmail.com \\ Universidade Estadual do Centro-Oeste/UNICENTRO-Guarapuava/PR
}

\begin{abstract}
RESUMO: A precipitação pluviométrica é um dos elementos climáticos mais abordados em estudos do clima para regiões tropicais e subtropicais. Isso se justifica pela alta intensidade das chuvas em ambientes tropicais e alta variabilidade encontrada em locais úmidos, como ocorre em boa parte do Sul do Brasil. Selecionando-se ambientes urbanos em regiões subtropicais para entender a dinâmica da precipitação, o tema se torna mais esclarecedor ainda, pois a cidade passa a ser objetivo de análise também. Nesse sentido, a cidade de Guarapuava, localizada no centro-sul do Paraná, foi eleita como objeto de estudo, utilizando-se de pluviógrafos e pluviômetros analógicos para medir a altura da precipitação em pontos distribuídos pela malha urbana no período de Dezembro de 2015 à Novembro de 2016. Além da coleta de dados pluviométricos a campo, consideraram-se as chuvas frontais e convectivas, enquanto dinâmicas diferenciadas resultantes dos sistemas atmosféricos e das trocas de calor no ambiente. Os resultados obtidos foram analisados por meio de cartogramas elaborados no SURFER, versão 8.0. Por fim, a pesquisa realizada demonstrou que a maior ou menor concentração pluviométrica no espaço e no tempo está vinculada principalmente a sistemas frontais e está centrada nas regiões por onde entram as massas de ar (tropicais no verão e polares no inverno) na cidade. A chuva se espacializa pelos bairros seguindo os contornos do relevo, principalmente quando a quantidade pluviométrica é superior à média histórica.
\end{abstract}

Palavras- chaves: Precipitação, orografia, massas de ar.

PLUVIOMETRIC PRECIPITATION DYNAMICS IN THE CITY OF GUARAPUAVA-PR-BRAZIL: LOCAL AND REGIONAL CONDITIONINGS

ABSTRACT: Pluviometric precipitation is one of the climate elements more approached in climate studies about tropical and subtropical regions. This is justified by the high intensity of rain in humid environments and high variability founded in wet locations, as it occurs in a great part of the south of Brazil. Selecting urban environments in subtropical regions to understand the precipitation dynamics, the issue becomes still more revealing, because the city changes to be a goal of analyses too. That way, the city of Guarapuava, located in the south center of the state of Paraná, was handpicked as a study object; it was used analogical pluviographs and rain gauges to measure the precipitation height in points distributed along the urban mesh in the period from December 2015 until November 2016. In addition to the pluviometric data gathering at field, it was considered the frontal rains and convective, which resulting of the atmospheric systems dynamics. The results has gained was analyzed through of maps elaborated in the SURFER, version 8.0. Finally, the research made has showed that the biggest pluviometric concentration in space and time is linked mainly to fontal systems and it is concentrated in the regions where the air masses get in (humid in summer and polar in winter) in the city. The rain is dotted around along the neighborhoods following the edges of the relief, especially when the pluviometric volume is higher than the historical average

\footnotetext{
${ }^{1}$ Este artigo é resultante da análise de parte dos resultados da dissertação de mestrado da primeira autora, intitulada Dinâmica Climática Na Área Urbana de Guarapuava-Pr no Período de Dezembro/2015 à Novembro/2016. Defendida e aprovada em 03 de março de 2017 no Programa de Pós Graduação de Geografia na Universidade Estadual do Centro-Oeste (UNICENTRO).
} 
Keywords: Precipitation, orography, air masses.

\section{INTRODUÇÃO}

A Geografia se divide em vários ramos do conhecimento, alguns deles considerados até ciência autônoma, como é o caso da Climatologia, a qual estuda, descreve e analisa os fenômenos atmosféricos em escala temporal ampla (algumas décadas). Além disso, procura compreender esses processos e as interações com a dinâmica da atmosfera e na sua interface atmosferasuperfície terrestre. A Climatologia enquanto ramo geográfico, além de ter essa característica, ainda busca associar a dinâmica meteorológica com o uso e a ocupação do espaço habitado, pois a sociedade humana é extremamente importante nesse processo.

O estado do Paraná, situado na região Sul do Brasil, apresenta características peculiares em relação ao clima. De acordo com Simões (1954 apud BALDO, 2006) o estado do Paraná classifica-se como sendo uma região de transição entre dois diferentes regimes: o clima tropical, atuante desde o planalto paulista para o norte e o clima mesotérmico úmido, que caracteriza a Região Sul do Brasil, de modo geral, e que se poderia denominar de subtropical. Sendo assim, essa transição se reflete, sobretudo, no regime pluviométrico, pois é no Paraná que se estabelece a passagem do regime de chuva de verão para o regime de chuvas mais bem distribuídas por todo o ano.

Essa característica de transição climática está associada a um conjunto de fatores. Alguns de ordem estática como a orografia e outros de ordem dinâmica como os sistemas atmosféricos, que, associados, interagem simultaneamente (NIMER, 1989).

O Paraná apresenta um relevo acidentado dividido em três planaltos, nos quais se destacam grandes escarpas que os delimitam. Estas, por sua vez, exercem influência na distribuição das precipitações, atuando simultaneamente como obstáculos orográficos (MAACK, 1968).

Dessa maneira, a características meteorológicas (dinâmica atmosférica) e de superfície (relevo) parecem estar totalmente vinculadas na região do Paraná. Nesse sentido, Penteado (1978) saliente que para se compreender a dinâmica atmosférica é necessário primeiro entender os fatores e elementos climáticos, partindo do pressuposto de que o relevo é um atributo importante na dinâmica climática local, podendo exercer influência na espacialização da precipitação.

Os fenômenos de superfície são comandados também pela dinâmica da atmosfera, tendo os fatores climáticos importância na variabilidade desses fenômenos. Ayoade (1998) ressalta que as áreas montanhosas recebem mais precipitação que os terrenos baixos. Portanto, a influência das montanhas sobre a precipitação fica condicionada ao seu tamanho e também ao seu alinhamento, relativo aos ventos, portadores de umidade e que potencialmente provocam chuvas.

Em uma atmosfera estável, a influência orográfica restringe-se à proximidade da montanha ou da escarpa, de maneira que a ação principal do terreno elevado é apenas redistribuir a precipitação, limitando essa influência 
na quantidade de precipitação ao seu redor, favorecendo alguns lugares e desfavorecendo outros.

Pinto e Neto (2008) complementam que o relevo é de grande importância para os estudos de clima local, principalmente quando se enfatiza o fator resfriamento catabático. Nesse processo o ar é forçado a ascender pela influência da barreira montanhosa, originando as chuvas orográficas a barlavento e, quando a umidade consegue ultrapassar esta barreira, chega em menor quantidade ao outro lado - sotavento.

Portanto, este fator climático (orografia) norteou a presente pesquisa, apesar de a relação sociedade/natureza, de forma ampla, também ter sido objeto do presente estudo, pois o mesmo abordou a dinâmica da precipitação pluviométrica na área urbana de Guarapuava-Pr.

Propõe-se então, como hipótese de trabalho, que a dinâmica pluviométrica da região está fortemente ligada ao fator relevo. Principalmente pelo fato de que as massas de ar oriundas de Sul e Sudeste, notadamente a Polar Atlântica (mPa), atuam intensamente no inverno de Guarapuava, e as Massas Tropical Atlântica (mTa) e Tropical Continental (mTc), atuam mais no verão. Intermediando a ação dessas massas existe uma barreira montanhosa chamada Escarpa da Serra da Esperança a Oeste da cidade (área de estudo). Essa escarpa atua como condicionante físico para atuação desses sistemas e, portanto, influencia sistematicamente as condições do tempo no local e suas adjacências. Devido a este fator orográfico e a própria configuração do relevo local (ondulado), a influência orográfica foi de grande importância neste estudo.

Além da Escarpa da Serra da Esperança, considerada numa escala mais ampla (município e região), na área urbana de Guarapuava o relevo é bastante ondulado. Assim, o presente estudo buscou confirmar a influência desse fator na variabilidade pluviométrica em mesoescala e também local (podendo chegar a microescala).

Além de o fator orográfico poder ser determinante para a distribuição das chuvas, é necessário entender também a atuação das massas de ar e como elas influenciam na dinâmica atmosférica, muitas vezes ultrapassando a barreira orográfica, aumentando a altura e a intensidade da precipitação.

\section{PRECIPITAÇÃO PLUVIOMÉTRICA E AS MASSAS DE AR}

A precipitação é um dos elementos climáticos de maior relevância para as atividades humanas, por isso é preciso entendê-la, tanto na sua evolução cronológica, quanto espacial.

Na Climatologia, o termo precipitação é usado para todos os tipos de deposição vindas da atmosfera em forma liquida e sólida. A precipitação pluviométrica pode ser medida através de pluviômetros, classificados em dois tipos básicos, os registradores e não registradores (AYOADE, 1998). Nesta pesquisa será considerada somente a precipitação líquida ou pluvial. Foram utilizados os dois tipos de pluviômetros - os registradores, que armazenam os dados, e os não registradores, em que as leituras são realizadas manualmente. 
A dinâmica da precipitação é diretamente influenciada pelos atributos geográficos e, portanto, se faz necessário saber os fatores condicionantes dessa relação.

Existem três tipos básicos de precipitação pluviométrica: (1) convectiva, associada às nuvens do tipo cumulonimbus que é causada pelo movimento vertical das massas de ar ascendentes, as quais são mais quentes que o meio ambiente. Normalmente acontecem no verão. (2) precipitação ciclônica ou frontal, causada por um movimento vertical do ar em grande escala, associada com os sistemas de baixa pressão com as depressões. E por fim, (3) precipitação orográfica, normalmente definida como aquela que é causada inteira ou principalmente pela elevação do ar úmido sobre o terreno elevado (acidentados ou montanhosos) (AYOADE, 1998).

Para que ocorra a precipitação é necessária a combinação de alguns fatores, destacando-se aqui as massas de ar, que, aliadas ao relevo podem ser determinantes para a ocorrência de chuva. As massas de ar são definidas como um grande corpo de ar horizontal e homogêneo que se desloca como uma entidade reconhecível, podendo ser tropical ou polar, modificando-se conforme sua locomoção. É influenciada por características térmicas da superfície e têm sua origem em áreas onde existem condições que favorecem o desenvolvimento de vastos corpos de ar horizontais e uniformes, (AYOADE, 1986).

As condições do tempo em um local específico, mesmo numa escala mais restrita, também são influenciadas pela ação das massas de ar predominantes, por isso Borsato (2016. p. 65.) salienta que:

O estado do tempo no dia em um determinado local é consequência das características do ar prevalecente, ou seja, de massas de ar ou da interação das duas ou mais massas de ares. Os tipos de tempo característicos de uma massa de ar, fria ou quente, úmida ou seca dependem da temperatura, da umidade relativa e da sua estrutura. Estes elementos serão alterados pelas condições locais, mas tendem a manter as características originais daquela massa de ar. Quando uma massa de ar afasta-se de sua região de origem, as suas características serão modificadas, mas as mudanças resultantes nos tipos de tempos são graduais no tempo e no espaço. Quando uma massa de ar dá lugar a outra, em uma determinada região, o tempo pode mudar abruptamente, às vezes com ventos violentos como acontece durante as passagens de um sistema frontal pelo Sul do Brasil.

No verão na região Sul, na qual está localizada a área de estudo (Guarapuava), ocorre a influência da Massa Tropical Continental (mTc) e da Massa Tropical Atlântica (mTa). No inverno, a mTa e a mTc perdem força e prepondera a atuação principalmente da Massa Polar Atlântica (mPa), (BORSATO, 2016).

No inverno a mPa tem mais intensidade na região sul, mas convém ressaltar que, no município de Guarapuava a mTc (Massa Tropical Continental), e a mTa (Massa Tropical Atlântica) também atuam, ainda que como um eficiente bloqueio aos sistemas polares durante o inverno austral e nas estações de transição (primavera e outono). Assim, o inverno em Guarapuava fica condicionado às chuvas frontais, principalmente (COSTA e ANDRADE, 2015). 


\section{CARACTERÍSTICAS GEOGRÁFICAS E CLIMÁTICAS DA ÁREA DE ESTUDO}

O município de Guarapuava está localizado na região Centro-Sul do estado do Paraná e tem o relevo como condicionante natural muito importante, pois apresenta cotas altimétricas que variam de aproximadamente 800 metros até mais de 1200 metros. No caso da área urbana da cidade (objeto central do estudo), seu sítio se localiza dentre as cotas mais elevadas do município (de 900 a 1140 metros).

De acordo com a Lei Municipal no 2016/2011 houve uma ampliação do perímetro da área urbana do distrito sede de Guarapuava. Atualmente a área urbana abrange $73,3 \mathrm{KM}^{2}$. A partir desta ampliação, a cidade passou a ter 25 bairros, conforme Figura 1, (GUARAPUAVA, 2011).

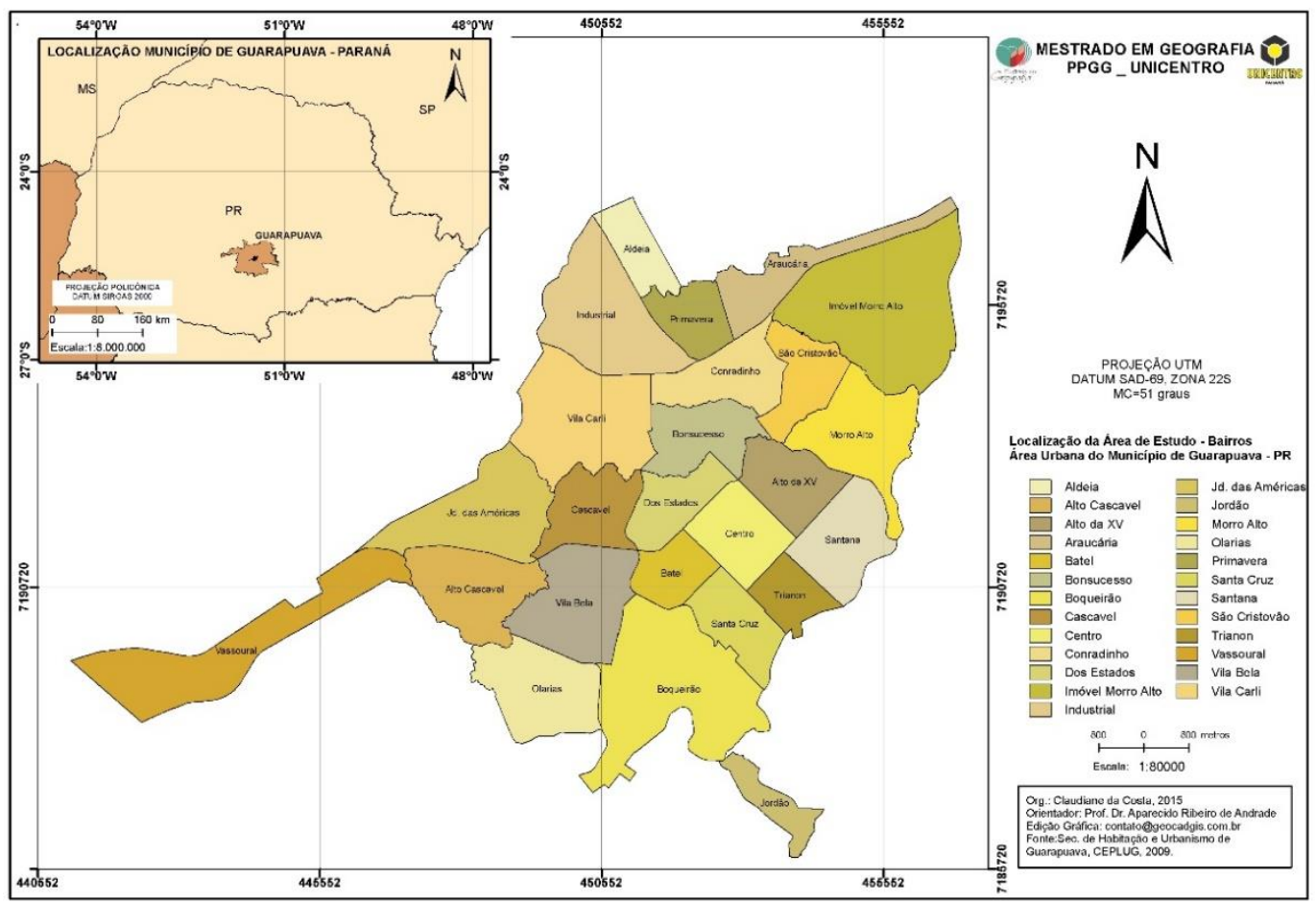

Figura 1 - Localização da área de estudo/área urbana de Guarapuava

O clima de Guarapuava, segundo a classificação de Köppen, pode ser descrito como subtropical mesotérmico-úmido, ficando na zona de clima extratropical do Paraná, e sem estação seca definida. A região tem como fatores decisivos para definição da variabilidade da precipitação e da temperatura, a altitude e o afastamento do mar. A temperatura média anual é de $17^{\circ} \mathrm{C}$ e a precipitação média de $1961 \mathrm{~mm}$. No inverno apresenta temperaturas negativas, podendo ocorrer geada com frequência e até mesmo, esporadicamente, a ocorrência de neve, (THOMAZ e VESTENA, 2003). Em contrapartida, no verão essas ocorrências são praticamente inexistentes e a altitude exerce influência nessa dinâmica. 
De acordo com as médias históricas (período de 1976 a 2016), verificase que para a escala mensal, a precipitação pluviométrica de Guarapuava se apresenta com os meses mais chuvosos sendo janeiro, outubro e dezembro (acima de $180 \mathrm{~mm}$ ) e o mês com menos chuva sendo agosto, com média de $93 \mathrm{~mm}$. As temperaturas médias do período são amenas na maioria das estações do ano (abaixo dos $30^{\circ} \mathrm{C}$ ), com destaque para o inverno, no qual as temperaturas mínimas normalmente ficam abaixo dos $10^{\circ} \mathrm{C}$ e as máximas não ultrapassam os $20^{\circ} \mathrm{C}$ (Figura 2).

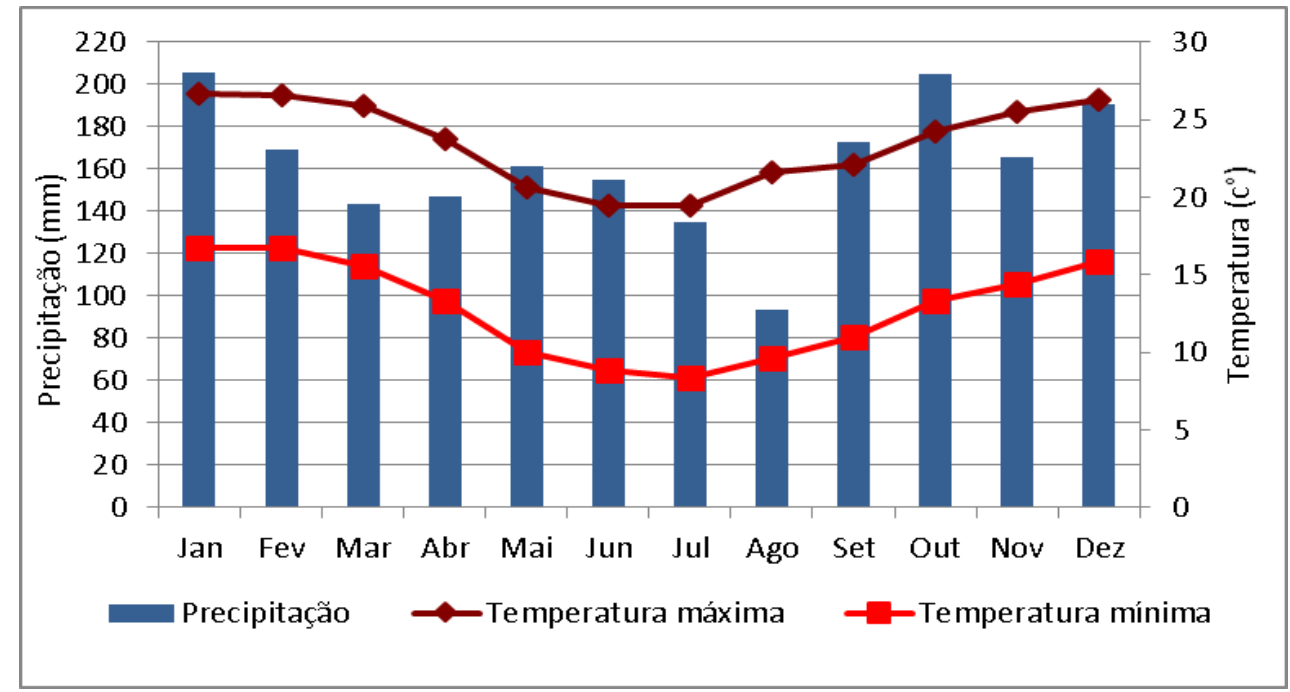

Figura 2 - Precipitação e temperatura mensal de Guarapuava no período de 1976-2016 Fonte: IAPAR, 2016.

É necessário ressaltar que além do relevo paranaense, outros condicionantes do clima exercem influência na dinâmica da precipitação no estado, como o evento El Niño (anomalias positivas da Temperatura da Superfície do Mar - TSM no Oceano Pacífico) e a La Niña (anomalias negativas de TSM no Oceano Pacífico). No entanto, estes fenômenos meteorológicos atuam no Sul do país como um todo e seu efeito local nem sempre é comprovado, (BEREZE, 2016).

De acordo com Souza (2006) nas regiões Sul e Sudeste do Paraná os eventos de El Niño e La Niña são responsáveis pelos desvios em relação às Normais Climatológicas, mas a intensidade do fenômeno El Niño e a Oscilação Sul (ENOS) ocorrem de forma diferenciada no estado, sendo que a região Sul do país sofre intensamente com o fenômeno, ao contrário da região Norte, mas esse processo não é homogêneo.

Neste sentido, Guarapuava - localizada no Centro-Sul paranaense pode ter sua precipitação influenciada por essas anomalias. De acordo com Bereze (2016), ao analisar uma série de 24 anos (1990-2013), foram constatados cinco episódios de La Niña e sete de El Niño. Cinco destes eventos apresentaram correlação com a precipitação de Guarapuava, sendo eles em 2003 e 2009 (El Niño fraco), em 1994 (El Niño moderado), em 1997 (El Niño forte), e em 2001 (La Niña moderada). 


\section{MATERIAIS E MÉTODOS}

A dinâmica da precipitação pluviométrica na cidade de Guarapuava foi mensurada a partir da instalação de pluviômetros analógicos e pluviógrafos ao longo da malha urbana, contemplando diferentes cotas altimétricas e também diferentes bairros (periféricos e centrais), considerando-se a diferenciação de adensamento urbano e cobertura do solo, (Figura 3).

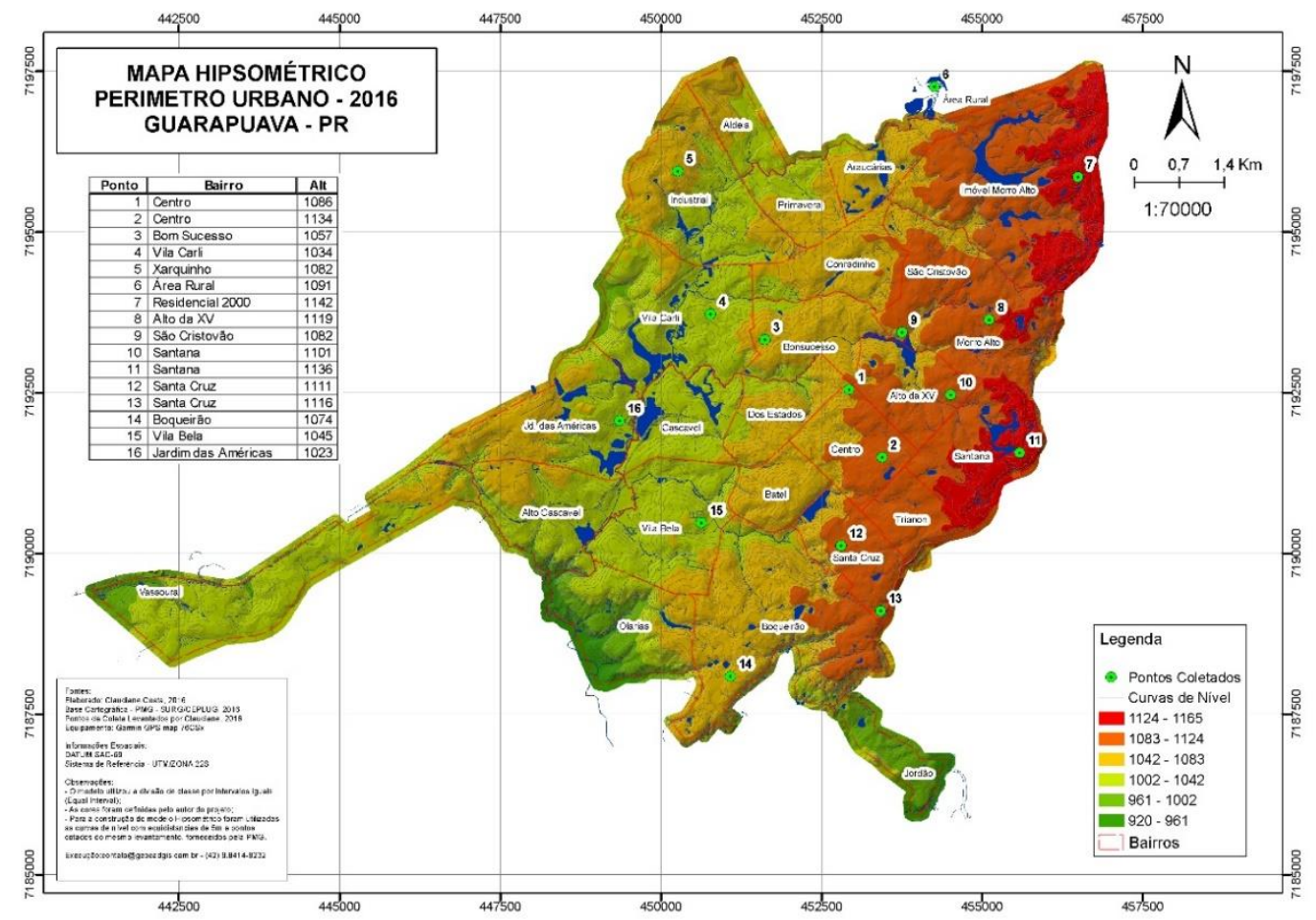

Figura 3 - Pontos de coleta dos dados espalhados pela malha urbana.Elaboração: Costa, C. 2016.

Os equipamentos utilizados foram: 6 pluviógrafos marca HOBO, com a capacidade de armazenar os dados da precipitação diária (não acumula a precipitação, somente os dados) e até mesmo horária, dependendo da autonomia desejada (Figura 4a). Além dos pluviógrafos, utilizaram-se 11 pluviômetros analógicos, que oferecem capacidade de armazenamento de 130 e $160 \mathrm{~mm}$. Esses últimos possuem capacidade de armazenamento diferentes em virtude da disponibilidade de aquisição encontrada, mas todos são da marca MULTITEC, com mesma acurácia/precisão (Figuras 4b e 4c). 


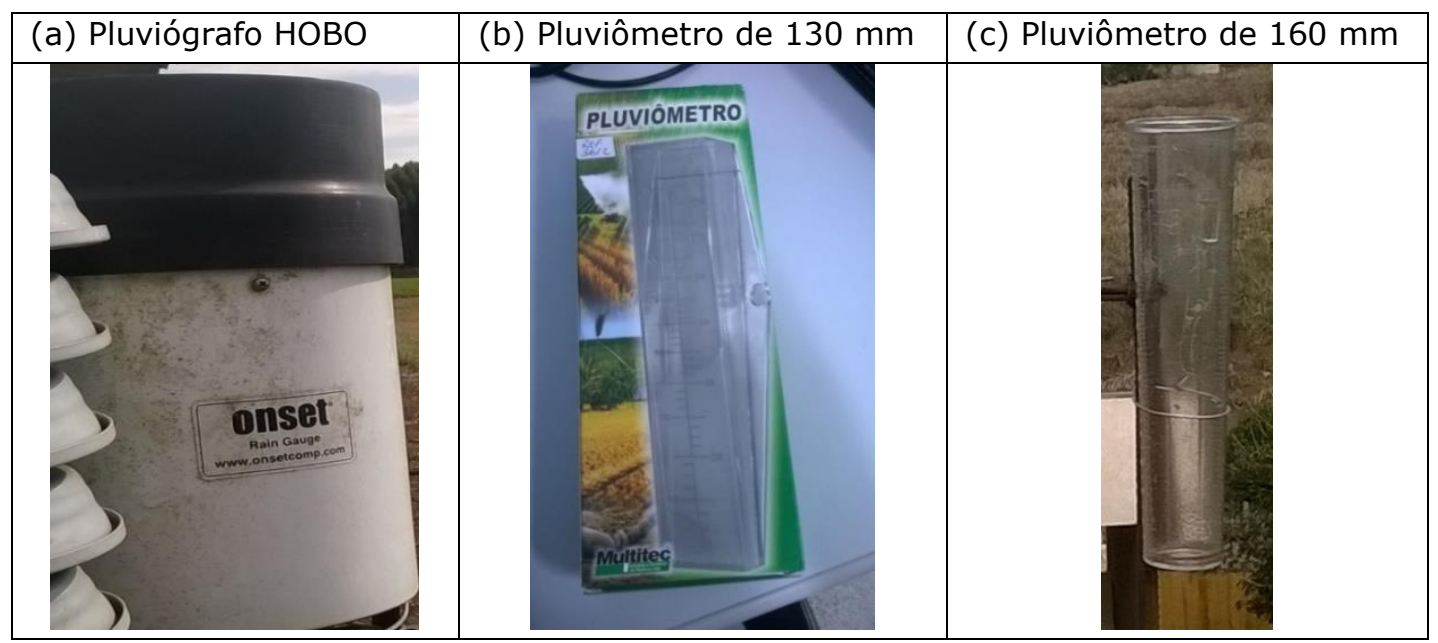

Figura 4 - Equipamentos de coleta dos dados. Fonte: Os autores.

Todos os equipamentos foram instalados em uma altura de 1,5 metros do solo, em locais que não havia influência de animais, pessoas ou objetos, como calha, poste, prédio ou vegetação.

Após a instalação dos equipamentos, foram realizadas saídas de campo (em média de duas a três vezes por mês), conforme a necessidade de atualização dos dados e a intensidade da precipitação ocorrida. O objetivo inicial era obter dados mensais da precipitação do dia primeiro ao dia trinta ou trinta e um de cada mês. Entretanto, em virtude de possíveis problemas nos equipamentos ou de influências externas, como a evaporação, podendo comprometer a mensuração da chuva, o período de coleta variou, adotando-se o período, por exemplo, do dia cinco até o dia cinco do mês seguinte.

A coleta dos dados foi realizada preferencialmente no início de cada mês (até o dia cinco), na metade do mês (entre os dias dez e vinte) e final do mês (depois do dia 25). Entretanto, como o estado do tempo foi monitorado constantemente, todas as vezes que se observava a precipitação intensa na cidade, realizavam-se coletas. No mesmo sentido, as coletas foram realizadas logo após eventos pluviométricos (no máximo após 3 dias) evitando o comprometimento dos dados (evaporação, por exemplo). Por isso, o intervalo entre as coletas ocorreram até quatro ou cinco vezes ao mês. Em seguida, os dados de chuva foram organizados em totais mensais de acordo com o volume acumulado, pois os pluviômetros analógicos não permitiram identificar a hora, dia e intensidade. Ainda que os pluviógrafos permitissem esse detalhamento, na busca de uniformizar os dados, considerou-se a quantidade mensal dos dois equipamentos.

Ao final, objetivando a análise mensal da precipitação e sua espacialização na área de estudo, os totais mensais foram interpolados utilizando-se o Software Surfer 8.0, e adotando-se a definição padrão que é a Krigagem ordinária utilizada para análise de tendência - a regressão linear. Além da análise mensal, também foi realizada uma breve análise sazonal, levando em consideração as estações do ano (verão, outono, inverno e primavera). As estações do ano foram definidas de acordo com o calendário agroclimático para a região sul do Brasil, ou seja, o trimestre do inverno é 
composto pelos meses de junho, julho e agosto. Consequentemente, a primavera é representada pelos meses de setembro, outubro e novembro, o verão por dezembro, janeiro e fevereiro e o outono está associado ao período de março a maio de cada ano.

O período de coleta dos dados (de dezembro de 2015 a novembro de 2016) foi necessariamente selecionado em virtude da realização da pesquisa para a dissertação de mestrado, procurando assim contemplar as quatro estações do ano dentro do período de integralização do curso.

\section{RESULTADOS E DISCUSSÕES}

No mês de dezembro de 2015 a precipitação pluviométrica superou a média mensal histórica que é de 190 mm (Figura 2, período de 1976-2016). Todos os pontos de coleta apresentaram mais de $250 \mathrm{~mm}$. No referido mês, observou-se que os maiores valores de chuva concentraram-se na porção leste, mas existe uma tendência geral de aumento de Sudoeste para Nordeste (Figura 5). Observou-se claramente a relação direta do aumento da chuva com a altitude, pois na área localizada a Sudeste, Leste e Nordeste da cidade encontravam-se os pontos de monitoramento de maior altitude dentro do perímetro urbano.

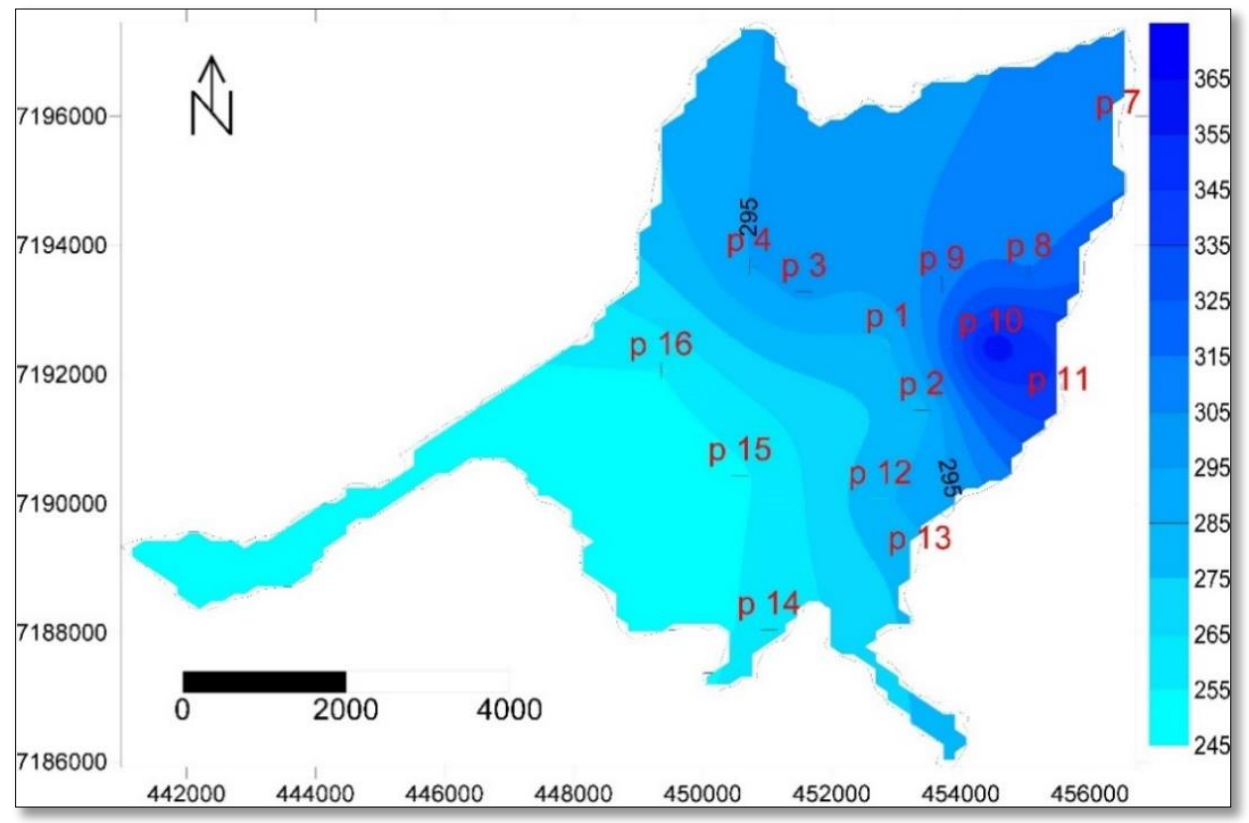

Figura 5 - Total da precipitação mensal dezembro de 2015

Os equipamentos utilizados foram: 6 pluviógrafos marca $\mathrm{HOBO}$, com a Em janeiro a quantidade de chuva foi menor que no mês anterior (205 mm), mas esteve dentro do esperado, como demonstra a média histórica apresentada na Figura 2.

Os pontos de coleta apresentaram uma variação entre 200 e 242 mm. Entretanto, observou-se que as chuvas se concentraram nos setores Noroeste 
e Sudoeste da cidade (Figura 6). Essa situação evidencia que em meses com altura de precipitação menores, a dinâmica intraurbana se diferencia, e as chuvas ocorrem em áreas com altitudes menores e com menos densidade urbana.

Apesar do mês de janeiro estar no verão austral e, portanto, as chuvas convectivas serem preponderantes, para a região de Guarapuava, os processos frontais podem ocorrer quando a $\mathrm{mPa}$ atua de forma mais intensa e o bloqueio da mTa e mTc estão enfraquecidos (BORSATO, 2016; COSTA e ANDRADE, 2015). Dessa forma, mesmo que esporadicamente essa influência exista, e como a região Sudoeste da cidade é o caminho natural das incursões, o efeito da orografia da malha urbana restringiu a maior concentração pluviométrica nessa região

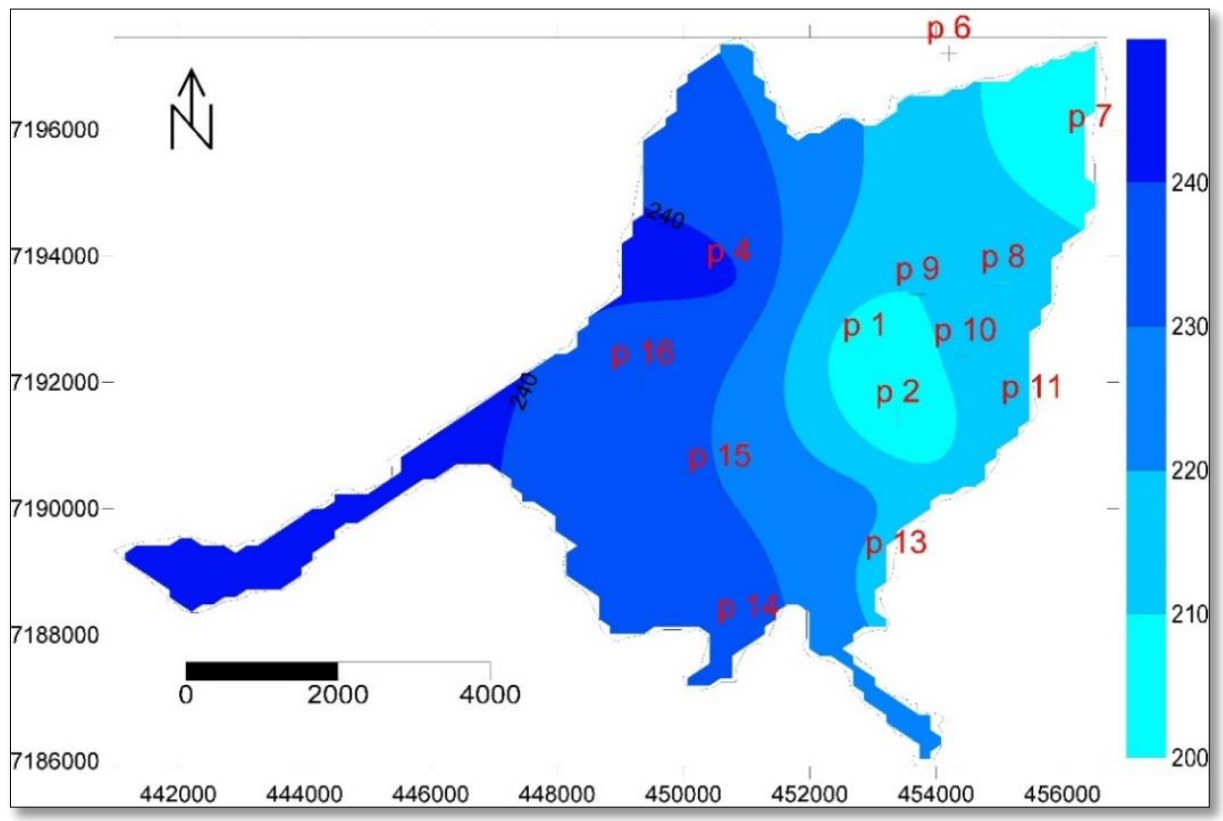

Figura 6 - Total da precipitação mensal Janeiro de 2016

No mês de fevereiro a quantidade de chuva superou a média de 169 $\mathrm{mm}$, que era o esperado. 0 ponto 9, com a maior quantidade pluviométrica, chegou a $378 \mathrm{~mm}$ (quase o dobro da média). Novamente choveu mais a Nordeste e Noroeste da área urbana (Figura 7). Essa situação é semelhante ao mês de Dezembro de 2015 em termos de espacialização, ainda que o acúmulo de precipitação tenha sido mais expressivo e acima da média, ou seja, agora preponderam chuvas convectivas em terrenos mais elevados e com maior densidade populacional. 


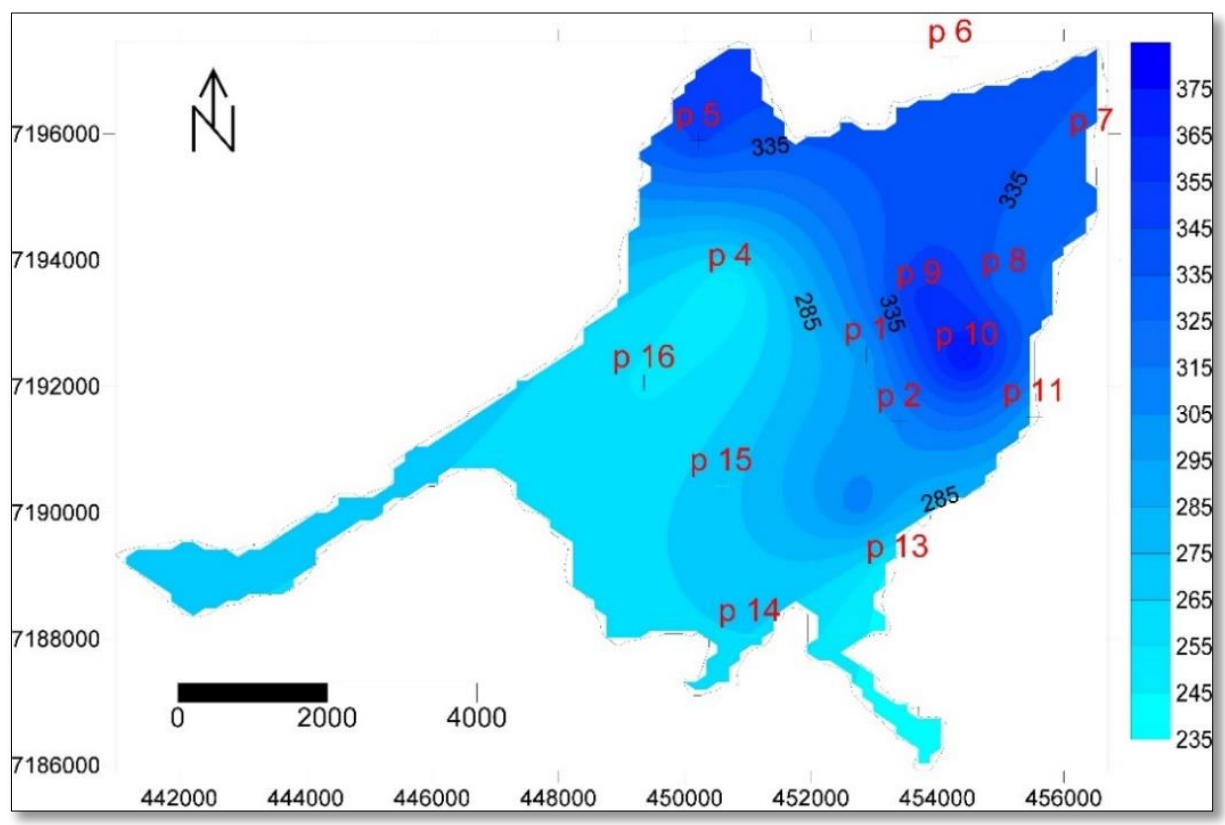

Figura 7: Total da precipitação mensal fevereiro de 2016

Sazonalmente, notou-se que dois meses do verão se destacam com volumes acima da média, no caso, dezembro e fevereiro. Nesse período as chuvas se concentraram a Nordeste e também um pouco a Sudeste da cidade, ou seja, nas áreas de maiores altitudes dentre os pontos de coleta. O mês de Janeiro se diferenciou, pois apresentou menor volume de chuva nos pontos de menor altitude ao Noroeste e Sudoeste.

Esta diferenciação pode ser explicada por episódios de chuvas locais, ou seja, convectivas. Apesar disso, não existe ainda estudos intra-regionais que possam comprovar tal hipótese, mesmo que seja provável. Além disso, as regiões Nordeste e Sudeste da cidade contêm mais pontos de coleta com maiores cotas altimétricas e também apresentam uma maior concentração de densidade urbana. Em contrapartida, quando os episódios de chuvas são resultantes da atuação de sistemas associados a massas de ares, se concentram a Sudoeste e também Noroeste, com chuvas mais moderadas (dentro da média). A região Noroeste se localiza numa área de transição em que recebe de forma alternada a influência dos processos convectivos e frontais. A convecção ocorre em períodos de maior insolação e isso se vincula a altimetria. Já a frontogênese está associada a sua posição geográfica (setor oeste), por ser a área de maior atuação dos sistemas mPa e mTc.

Em março a precipitação diminuiu novamente, conforme pode ser observado na Figura 8, e o ponto com maior pluviometria chegou somente a $165 \mathrm{~mm}$, localizado no Alto da XV. A diferença entre o ponto mais chuvoso e menos chuvoso foi de $79 \mathrm{~mm}$, destacando novamente a parte Nordeste da cidade, onde estão os pontos com cotas altimétricas mais elevadas. 


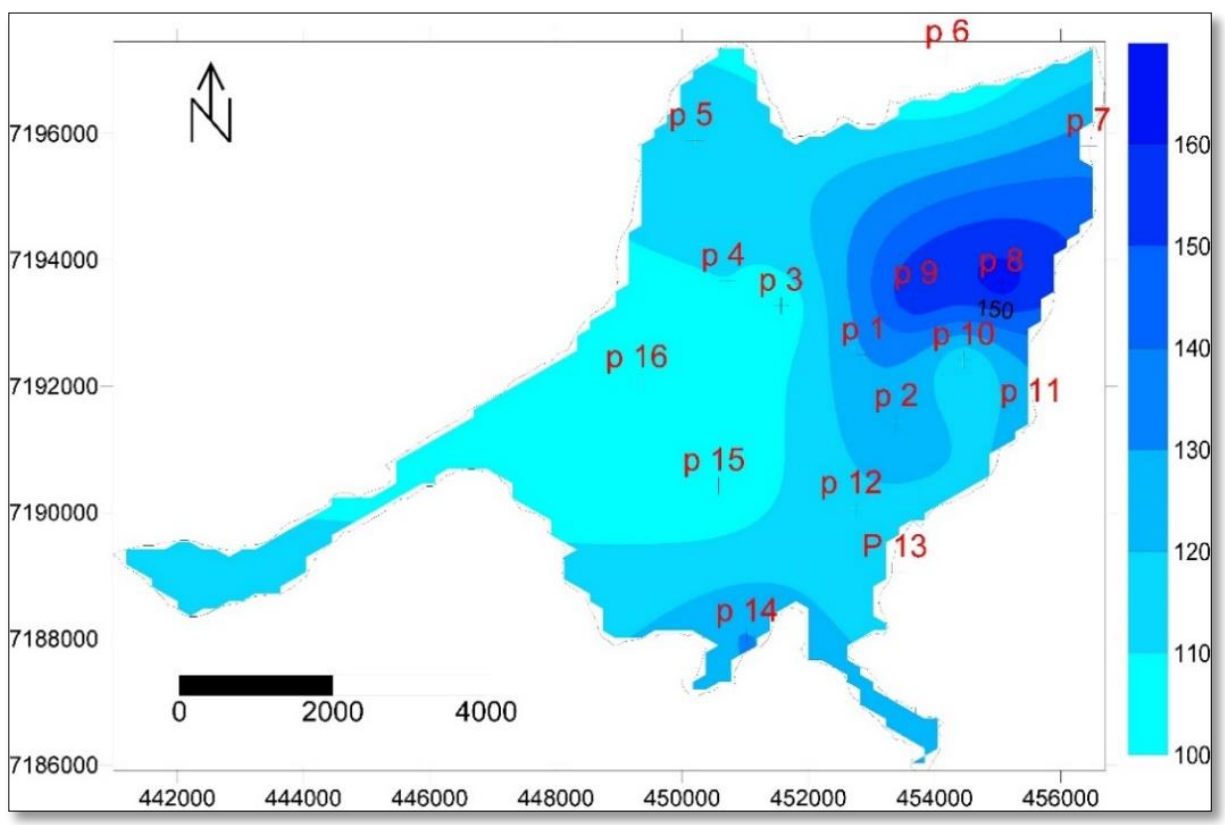

Figura 8: Total da precipitação mensal março de 2016

A média mensal para o mês de março é de $143 \mathrm{~mm}$ e a precipitação no período monitorado esteve dentro da média esperada. Mas ao contrário do que aconteceu no verão, houve um pequeno aumento da precipitação no ponto 8 , a Sudeste. No restante da cidade a distribuição foi relativamente homogênea. Apesar disso, nesse ponto (8) a chuva foi acima da média da cidade, evidenciando chuvas mais intensas causadas pelo efeito orográfico.

No mês de abril a precipitação diminuiu ainda mais em relação ao mês anterior. O ponto com maior volume acumulado durante o mês foi de 150,8 $\mathrm{mm}$ a Noroeste e o ponto com menor volume $(82 \mathrm{~mm})$ a Nordeste (Figura 9). Como as diferenças foram menores entre os pontos de coleta, neste mês a chuva ficou bem homogênea, melhor distribuída por toda a área urbana. Convém ressaltar que a média do mês é de $147 \mathrm{~mm}$, conforme pode ser observado na Figura 2. 


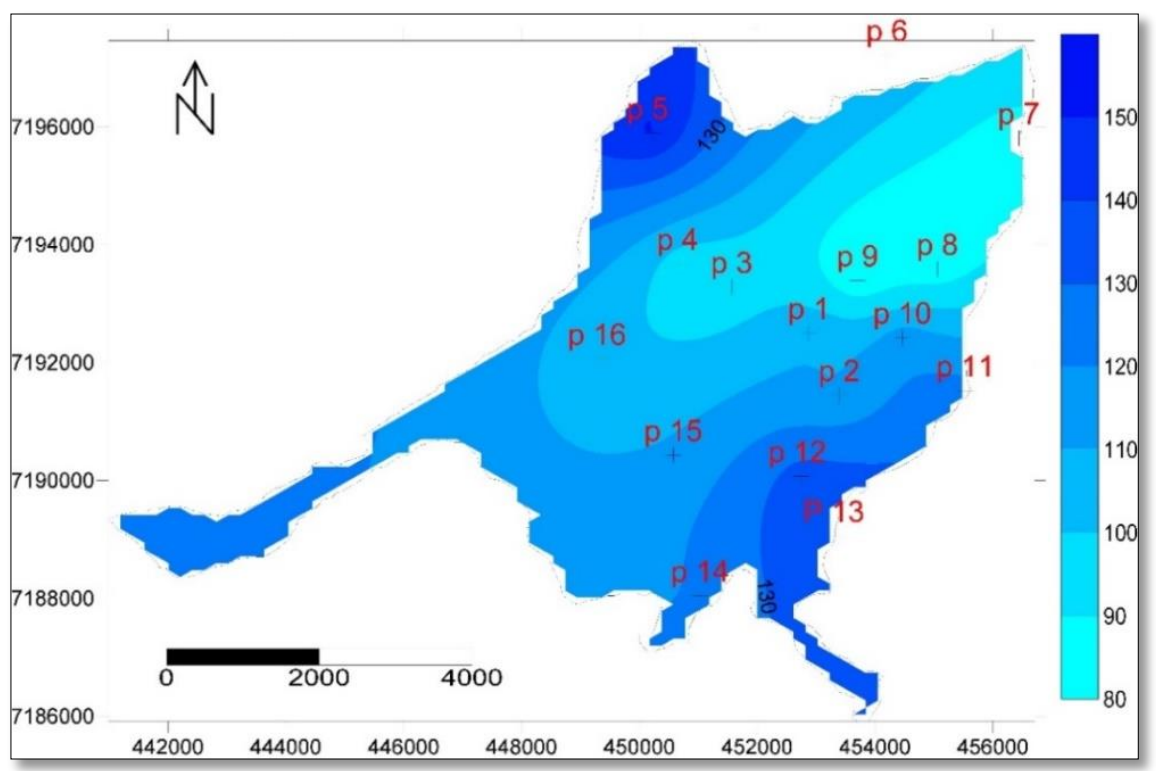

Figura 9: Total da precipitação mensal Abril de 2016

No mês de maio a precipitação aumentou em relação ao mês anterior. O ponto com maior volume foi de $192,6 \mathrm{~mm}$ a Noroeste e o de menor volume com $153,6 \mathrm{~mm}$ a Sudeste. Verificou-se pouca variação espacial para o mês, pois a média mensal é de $161 \mathrm{~mm}$ (Figura 2) e o volume registrado para o mês não se distanciou muito dessa média (Figura 10).

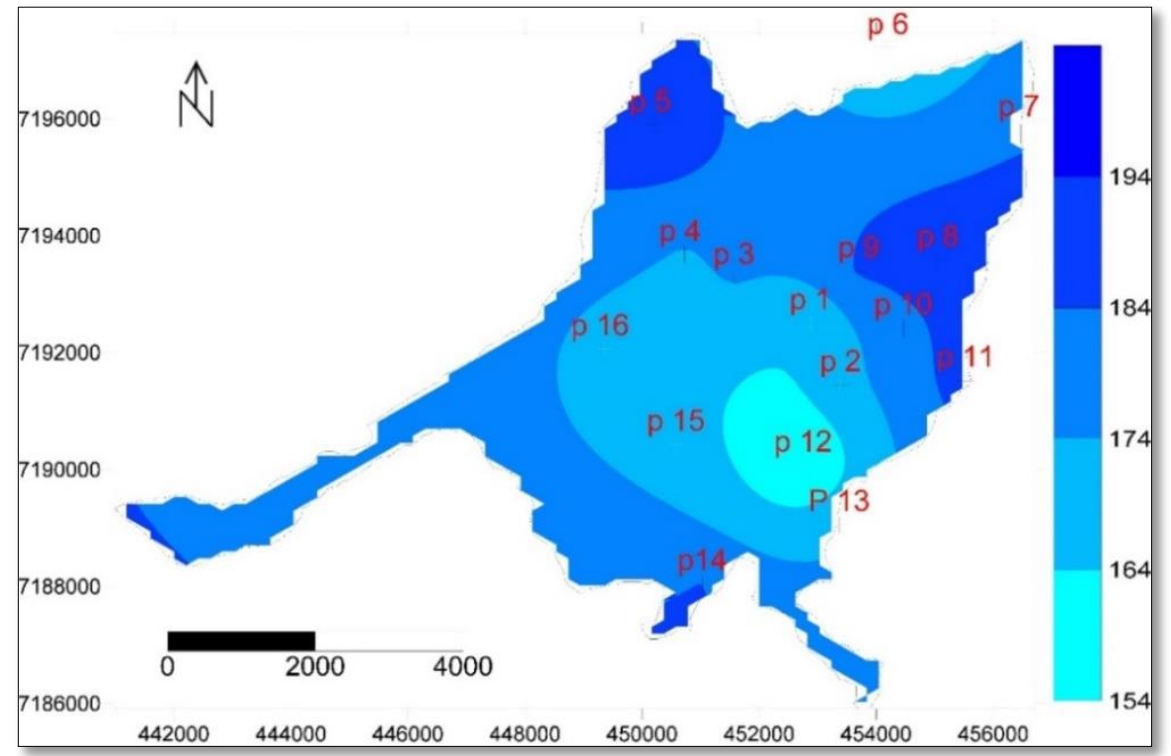

Figura 10: Total da precipitação mensal maio de 2016

Apesar de certa homogeneidade na distribuição, como a quantidade de chuva aumentou, o relevo passou a influenciar de forma mais significativa e a região Leste e Nordeste é que apresentaram maiores alturas de chuva. 
Dessa forma, no outono preponderaram as chuvas nos quadrantes Nordeste e Sudoeste da cidade, ainda que nesta estação a variação espacial não seja tão marcante. Nota-se, excepcionalmente no primeiro mês (março), que a região Nordeste concentrou maiores valores, provavelmente em virtude de maior insolação associada a altitude.

A média histórica para o mês de junho é de $154 \mathrm{~mm}$ (Figura 2). Em 2016, nesse mês, entre os pontos de coleta, o que chegou mais próximo da média foi o ponto 14 (Sul) com $122 \mathrm{~mm}$. Percebeu-se que os maiores valores de chuvas foram registrados a Sudeste e também em um ponto a Nordeste, conforme evidencia a Figura 11.

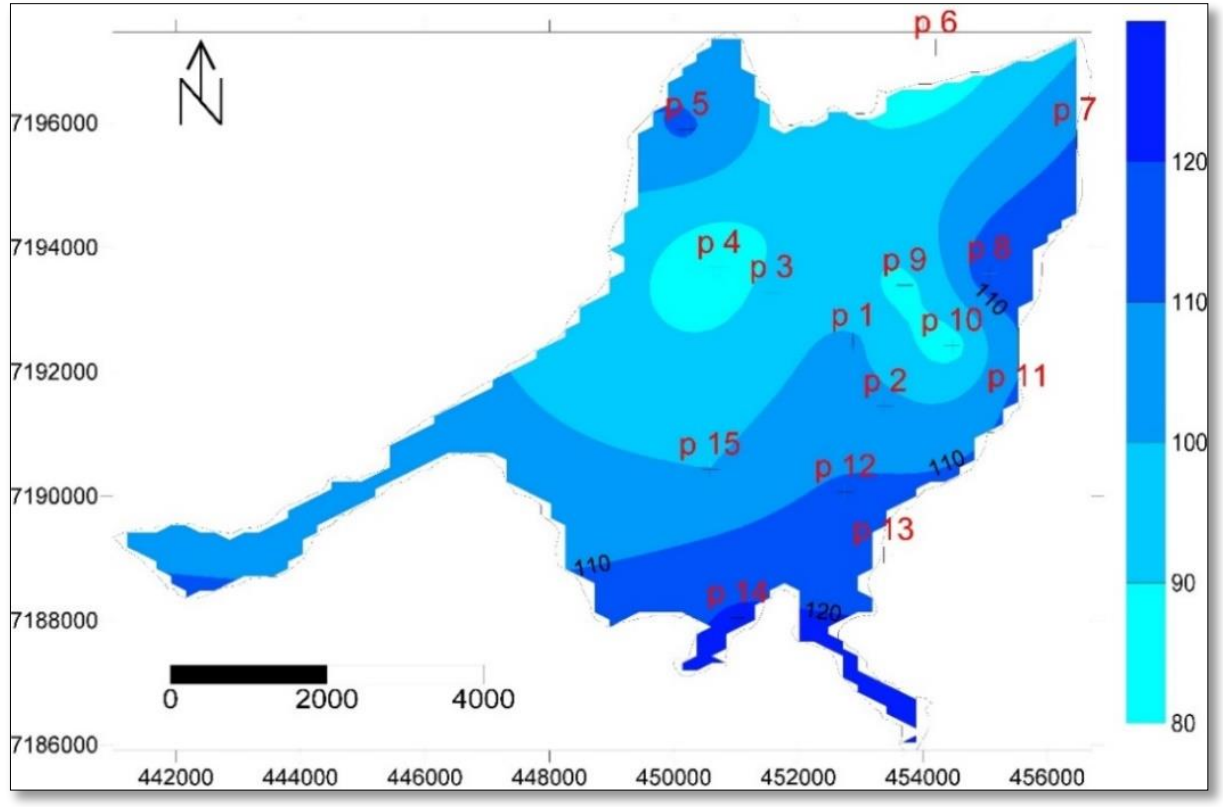

Figura 11: Total da precipitação mensal junho de 2016

Os pontos com menores quantidade de chuva (3, 4, 9 e 10) estão em diferentes altitudes, o que indica uma variabilidade também para as chuvas frontais impulsionadas pela $\mathrm{mPa}$, que tem forte atuação no inverno de Guarapuava.

Já no mês de Julho, com média mensal histórica de 134 mm (Figura 2), todos os pontos marcaram altura de chuva acima desse valor. Os pontos que obtiveram o menor volume foram 12 e 13, no quadrante Sudeste. As maiores alturas de chuva estão no Nordeste e Noroeste (Figura 12). Retorna-se, assim, o padrão identificado em meses anteriores, quando a chuva é mais intensa (análise mensal), e a orografia desempenha papel mais marcante. 


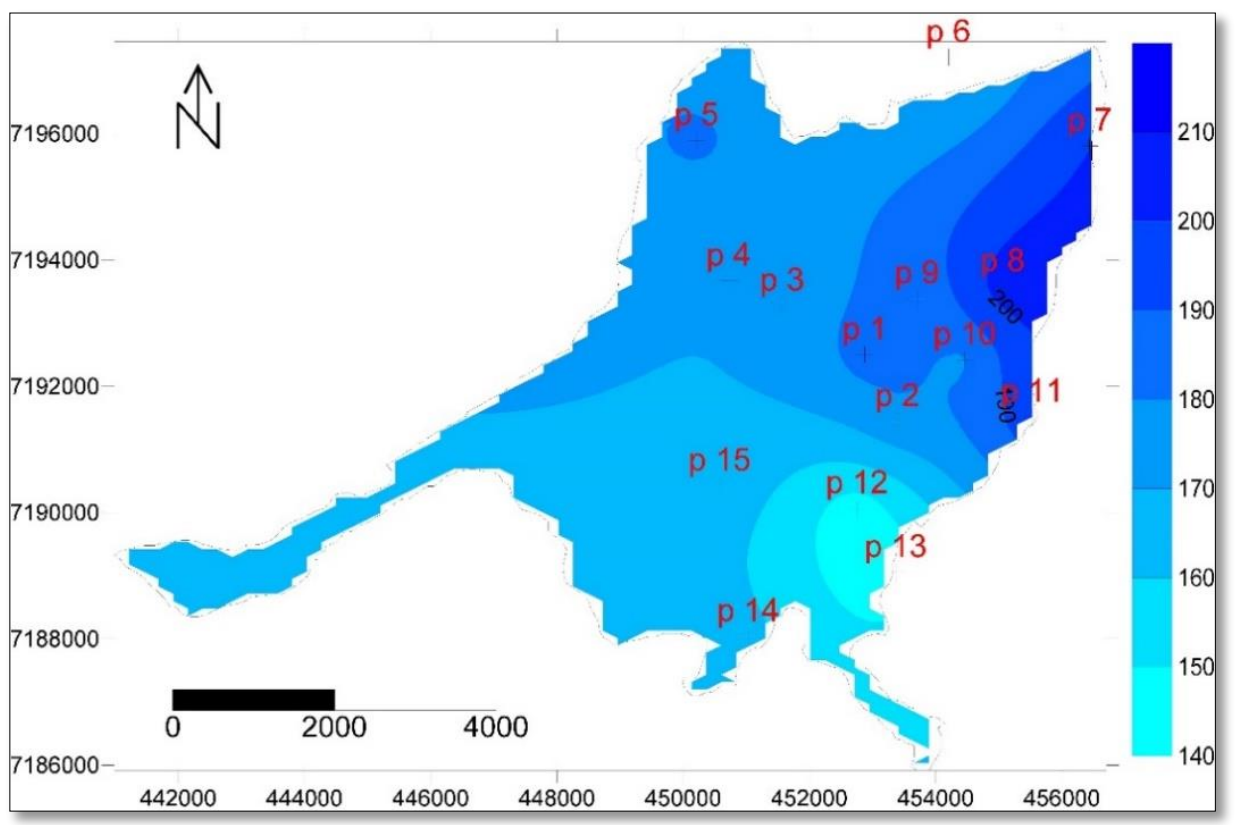

Figura 12: Total da precipitação mensal julho de 2016

Para o mês de agosto a média histórica é de $93 \mathrm{~mm}$, conforme apresentado na figura 2, porém a média entre os pontos de coleta nesse mês, em 2016, foi de $195 \mathrm{~mm}$, somando-se mais que o dobro do esperado. Observou-se então que os pontos com menor volume foram os pontos 14 e 15, com 186 e 184 mm, respectivamente (Figura 13). Nesse mês, apesar da distribuição ser menos homogênea, as quantidades mais expressivas de chuva voltaram a ocorrer nos setores Noroeste e Nordeste (parte mais alta da cidade).

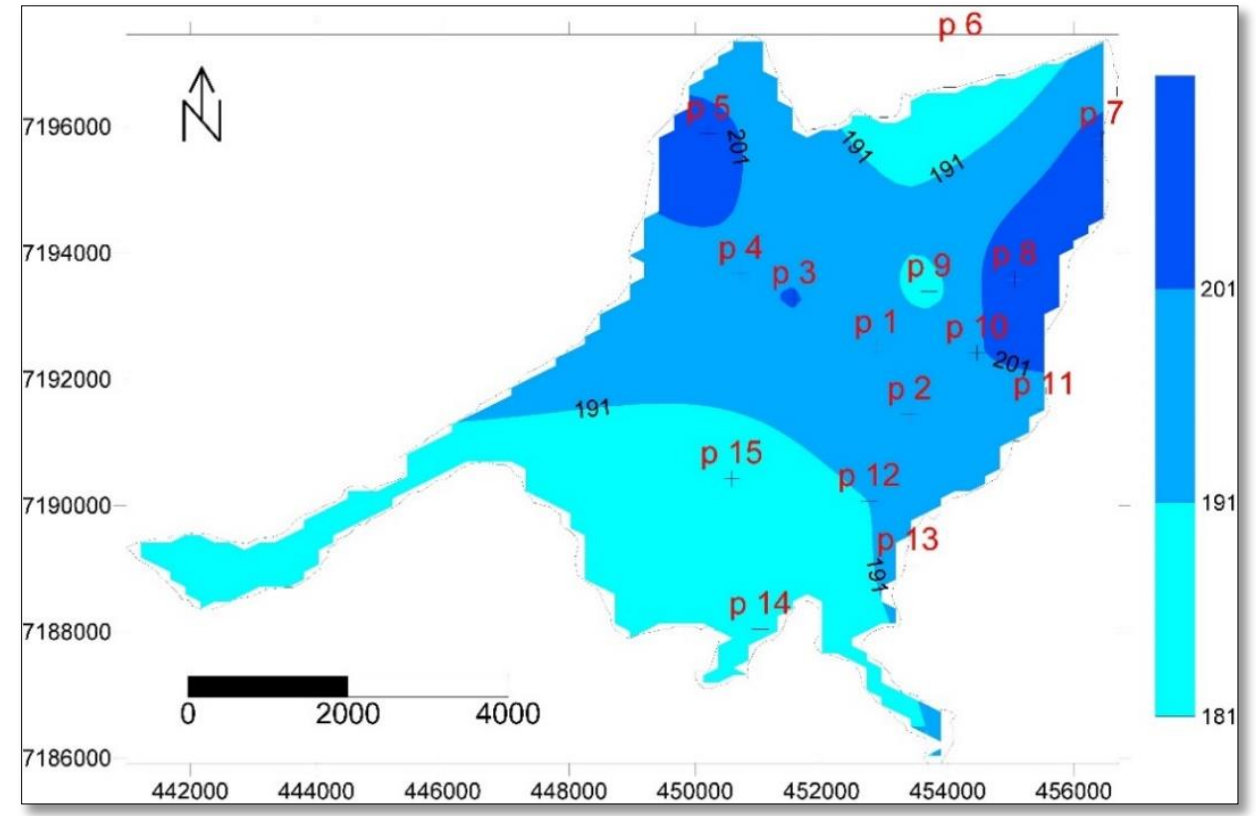

Figura 13: Total da precipitação mensal agosto de 2016 
Normalmente as chuvas de inverno em Guarapuava resultam de sistemas frontais impulsionados pela massa Polar Atlântica (mPa). Sendo assim, elas precipitam em maior volume na região de entrada das massas de ar na cidade (Sudeste e Sudoeste). Entretanto, quando a quantidade de precipitação é maior do que o normal, o controle da distribuição espacial passa a ser da orografia (relevo).

A média de precipitação para o mês de setembro é de $172 \mathrm{~mm}$, mas nesse mesmo mês, em 2016, nenhum dos pontos de coleta apresentou mais de $100 \mathrm{~mm}$ (Figura 14). Destacaram-se os pontos 2, 7 e 11 (com maior volume acumulado). O primeiro no centro da cidade, o segundo a Nordeste e o terceiro a Sudeste. Estes três pontos possuem as maiores altitudes dentro da malha urbana. Esse foi um mês bem atípico, com chuvas abaixo do esperado e como é o início da primavera, esperava-se que as chuvas fossem predominantemente convectivas, mas o que se percebe é a preponderância da influência do relevo local, independente da atuação frontal ou convectiva.

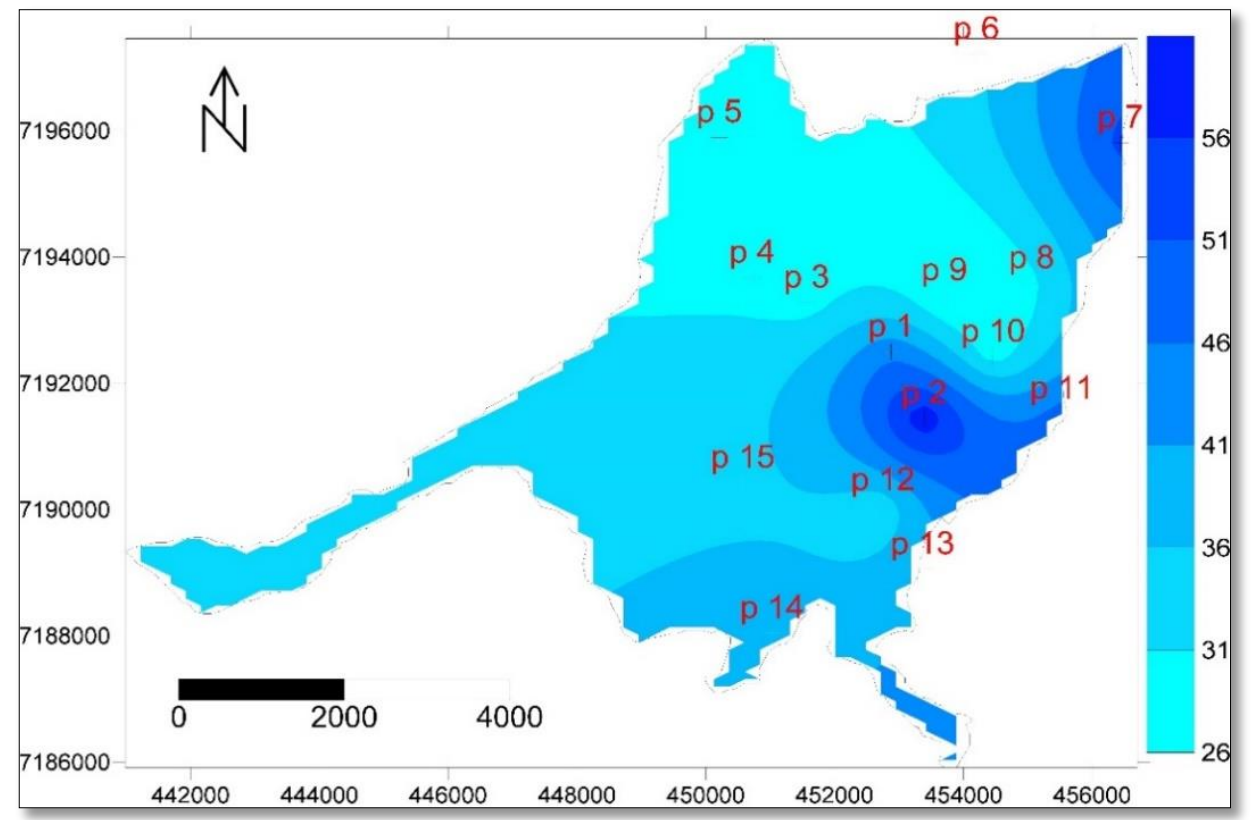

Figura 14: Total da precipitação mensal setembro de 2016

No mês de outubro, a média mensal é de $205 \mathrm{~mm}$, e a média entre os pontos de coleta em outubro de 2016 foi de 175, porém, o ponto 14 recebeu $209 \mathrm{~mm}$, sobressaindo aos demais. Nesse sentido, o Sul da cidade obteve a maior altura de precipitação (Figura 15).

No mês de outubro não foi possível encontrar uma explicação típica para o período (primavera). Normalmente se esperaria uma distribuição menos homogênea, com concentração de chuva nos pontos mais elevados e precipitações dentro ou acima da média, mas não foi isso que ocorreu. Uma possível explicação seria a atuação do El Niño de 2016, mas aqui fica apenas 
como suposição (possível hipótese), pois não foi efetuada investigação específica que permita afirmar tal relação.

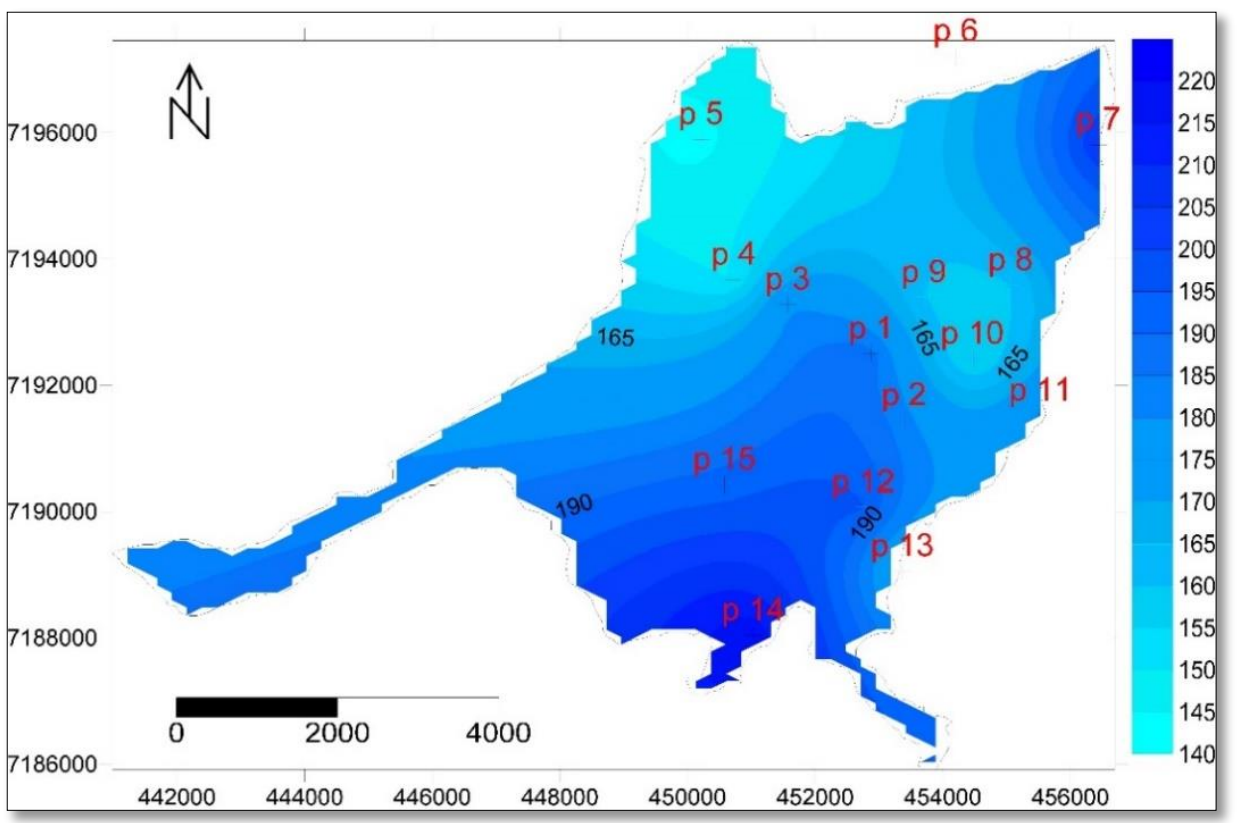

Figura 15: Total da precipitação mensal outubro de 2016

No mês de novembro, com média histórica de $165 \mathrm{~mm}$ (Figura 2), ocorreu $166 \mathrm{~mm}$ na média entre os pontos de coleta. Isso evidencia que em novembro choveu muito próximo do esperado. Os pontos com maiores volumes foram $1,2,3$ e 8 , além da região central da cidade e um ponto a Nordeste (Figura 16). Apesar de oscilar próximo da média histórica, a distribuição pluviométrica obedeceu a orientação do relevo do sítio urbano, enfatizando essa influência nesse mês. 


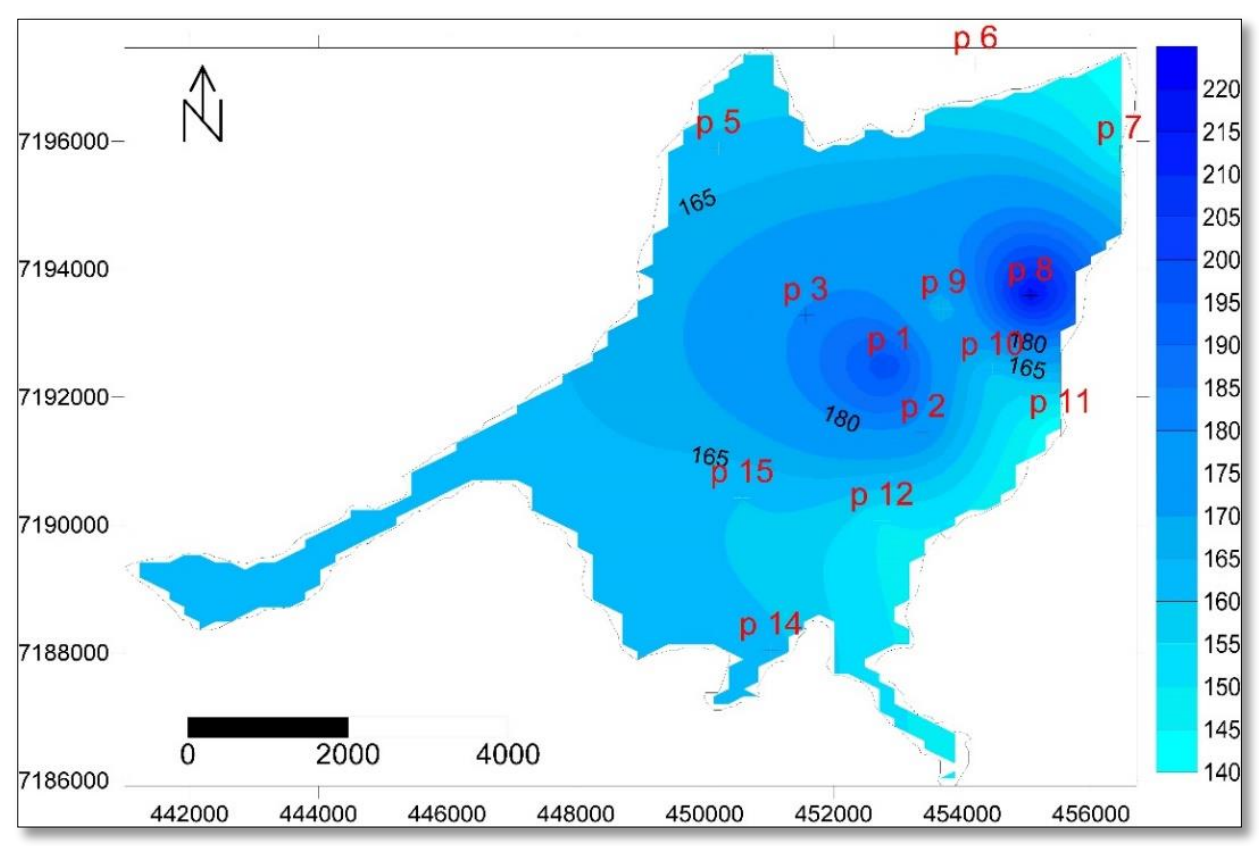

Figura 16: Total da precipitação mensal novembro de 2016

Na primavera a variabilidade espacial na precipitação, em relação às outras estações, foi diferenciada. Ainda que em setembro prepondere mais chuvas no Nordeste e Sudeste, nos meses restantes as chuvas se concentraram no Sudeste e Nordeste.

\section{CONCLUSÕES}

Quando analisado sazonalmente, os maiores valores de precipitação pluviométrica foram registrados nas partes Noroeste, Nordeste e Sudeste da cidade de Guarapuava. Em contrapartida, os menores valores ocorrem no setor Sudoeste. Como era de se esperar, as chuvas se distribuem de forma irregular no espaço e no tempo. No espaço, por conta do relevo, e no tempo, por causa dos tipos de chuvas que prevalecem em determinadas épocas do ano. Quando ocorrem chuvas com volumes mais elevados, mas bem distribuídos, resultantes de sistemas frontais impulsionados por massas de ares, têm-se uma maior homogeneidade, com pequena concentração no setor Sudoeste e, às vezes, a Sudeste, mas normalmente essas chuvas estão dentro ou próximas da média histórica.

De forma contrária, mas análoga, quando ocorrem chuvas acima da média, mas de forma concentrada (convectivas), são nas regiões Noroeste, Nordeste e Leste, que têm maiores volumes de chuva. Essa dinâmica evidencia que o controle do relevo é o que mais prevalece.

Dessa forma, conclui-se que a dinâmica da precipitação pluviométrica está diretamente ligada ao movimento das massas de ar. Em períodos em que ocorreram alturas de precipitação próxima da média histórica, houve uma 
espacialização mais homogênea pela cidade. Já em períodos com eventos mais intensos, além da influência das massas de ar, ocorre também influência do relevo, independente da estrutura urbana.

Ao longo da análise não foi possível obter uma relação da variabilidade pluviométrica com a urbanização, pois a parte central da cidade, com maior adensamento urbano, não necessariamente concentrou as maiores quantidades de chuva.

$\mathrm{Na}$ maioria dos meses analisados, ficou evidente que a dinâmica da precipitação em Guarapuava decorre da influência da orografia e das massas de ar. Somente em três meses (março, setembro e outubro) não foi possível identificar necessariamente uma relação direta das chuvas com a circulação atmosférica e nem com o relevo, mas também não foi possível associá-la à estrutura urbana.

\section{AGRADECIMENTOS}

Os autores agradecem ao Instituto Paranaense Agronômico do Paraná (IAPAR) pela disponibilidade dos dados históricos de temperatura e precipitação. A primeira autora agradece a Coordenação de Aperfeiçoamento de Pessoal de Nível Superior (CAPES) pela bolsa recebida durante a realização do mestrado.

\section{REFERÊNCIAS BIBLIOGRÁFICAS}

AYOADE, J. O. Introdução à Climatologia para os Trópicos. $5^{a}$ Edição, Rio de Janeiro: Bertrand do Brasil, 1998.

BALDO, M.C. Variabilidade pluviométrica e a dinâmica atmosférica na bacia hidrográfica do rio Ivaí - Pr. Tese (Doutorado) Universidade Estadual Paulista. São Paulo, 2006

BEREZE, J. Relação entre a variabilidade climática e a produtividade de batata em Guarapuava - Paraná. Dissertação (Mestrado). Programa de PósGraduação em Geografia. Unicentro - Universidade Estadual do Centro-Oeste, Guarapuava-PR, 2016.

BORSATO, V.A. A dinâmica climática do Brasil e massas de ares. 1.ed. Curitiba, Pr: CVR, 2016

COSTA, C. e ANDRADE, A. R. Gênese e evolução das temperaturas mínimas absolutas na região centro-sul do Paraná: A influência da dinâmica atmosférica e do relevo local. Boletim goiano de geografia (Online) v. 35, n. 3, p. 452471, Goiânia, 2015

GUARAPUAVA, Lei ordinária no 2016/11 de 20/12/11. Súmula; autoriza o executivo municipal a alterar o Perímetro da Área Urbana do distrito sede de Guarapuava. Guarapuava, 2011

IAPAR, Instituto Agronômico do Paraná. Dados de temperatura e precipitação.

MAACK, R. Geografia física do Estado do Paraná. Curitiba: José Olympio, 1968

NIMER, E. Climatologia do Brasil. 2.ed. Rio de Janeiro: Fundação IBGE, 1989. 
PENTEADO, Margarida Maria. Fundamentos de geomorfologia. 2, ed. Rio de Janeiro: IBGE, 1978.

PINTO, J.E.S.S e NETO, A.O.A. Clima, Geografia e Agrometeorologia; uma abordagem interdisciplinar. São Cristóvão: Editora UFS, Aracaju: Fundação Oviêdo Teixeira, 2008.

SOUZA, P. Estudo da variabilidade da precipitação no Estado do Paraná associado à anomalia da TSM no oceano Pacífico. Dissertação (mestrado)Universidade Estadual de Maringá. Programa de Pós Graduação em Geografia, Maringá, 2006.

THOMAZ, E. L. VESTENA, L. R. Aspectos climáticos de Guarapuava-PR Guarapuava: UNICENTRO. 2003. 